\title{
Heterosis And Combining Ability Estimates In 6x6 Half-Diallele Cross Of Roselle (Hibiscus Sabdariffa L.)
}

\author{
S.J. Louis*, S.Y. Simon \\ Department of Crop Production and Horticulture Modibbo Adama University of Technology, P.M.B 2076, Yola, \\ Nigeria.
}

\begin{abstract}
Half diallele analysis was used to identify the high heterotic crosses and their relationship in terms of general combinig ability (GCA) and specific combining ability (SCA) of 6 roselle cultivars evaluated in two locations Yola and Mubi, located within latitude $7^{\circ} 14^{\prime}$ North, Longitude $12^{\circ} 38^{\prime}$ East and Latitude $10^{\circ} 03^{\prime}$ North, Longitude 13 ${ }^{0}$ 07' East respectively in Adamawa State, Nigeria. The results showed significant entries, parents and crosses for all the traits studied in the individual and also in the poolled analysis, suggesting that roselle populations were highly variable for all the traits and therefore would most likely respond to selection. Significant GCA and SCA variances were also obtained in all the traits implying that both the additive and nonadditive gene effects were operating in the genetic expression of the traits. The non-additive gene effect was however greater in magnitude as shown by the $\delta^{2} G C A / \delta^{2} S C A$ ratios, which were all less than unity. The combining ability analysis of parents also revealed that Gerio-AB3, Bazza-AB2 and Bazza-AB1 yielded consistently higher general combining ability effect for most of the traits, indicating that their crosses should produce desirable segregates for the improvement of calyx yield of roselle. SCA effects identified Bazza-AB2 $x$ Gerio-AB2, Bazza-AB1 x Gerio-AB3 and Bazza-AB1 x Michika-AB1 as the best crosses. The hybrid Bazza-AB2 $x$ Gerio-AB2 exhibited heterosis of up to $46.01 \%$ over the higher yielding parent.
\end{abstract}

\section{Introduction}

Heterosis works as a basic tool for improved production of crops in the form of $F_{1}$ hybrids. Plant breeders have widely exploited and used heterosis in boosting up yield of many crops. Therefore, the heterotic studies can provide the basics for the exploitation of valuable hybrid combinations in the future breeding programmes and their utilization. Most traits of economic importance are qualitative and controlled by several to many major genes. Generally heterosis can be divided into two broad categories, true heterosis and psuedoheterosis. In case of true heterosis, there is an increase in general vigour, yield and adaptation. In case of psuedoheterosis, the $F_{1}$ hybrid exhibits increase in vegetative growth only. It refers to the superiority of $F_{1}$ over the standard commercial check variety. So, it is also called economic heterosis or superiority over checks (Sharief et al., 2009). Resently it has been divulged that the utilization of heterosis is extremely effective for the genetic improvement of different traits and that the concepts of combinig ability are the the fundamental tools for enhancing productivity of different crops in the form of $F_{1}$ hybrids (Flint-Garcia et al., 2009).

Roselle (Hibiscus sabdariffa L.), a tropical annual plant, which produces fruit-like structures containing edible pigments, belongs to the family Malvaceae (Ghazali, 1999). It is believed to have originated from India, but now widely cultivated throughout the tropical world for its calyxes, leaves and fiber (Gasim, 1994).

Roselle is one of the most medicinal plants, which has many applications in folk medicine in many countries of the world. In china, it is used for the treatment of hypertension, pyrexia and liver damages and recent studies demonstrated that the phenolic compounds of its sepals water extracts is effective in the treatment against leukemia. Moreover, water and fat extracts of roselle sepals and seeds present high antioxidant capacity, which may protect the cell against free radical damages. Also, the water extracts of the sepals have been useful in lowering high blood pressure (Ibrahim and Hussein, 2006) .

In Nigeria, roselle production is mainly in the guinea and sudan savannah zones of the country where red and green calyx genotypes are prevalent (Alegbejo, 2000). Roselle has become an important source of raw material for a beverage drink called "zoborodo" in northern Nigeria. The extract is usually sweetened with sugar and may be flavoured with other materials such as ginger, pineapple and strawberry. Its popularity has recently spread across the entire country because of its medicinal value as well as the increasing cost of other available soft drinks whose concentrates are mostly imported, causing a drain to the national economy (Adenipekun, 1998).

Several studies on roselle have been carried out, however little is reported on genetic improvement. Vaidya (2000) studied the natural out cross-pollination in roselle. Sanyal and Dutte (1984) found genetic variability in flowering date and calyx yield in two cultivars of roselle. Genetic investigation of transmission of various important characters has remained far from being fully explored; this is due to the fact that there is 
insufficient genetic information on various species and cultivars of roselle in Nigeria. For this reason, this research was conducted with the following objectives. To establish the magnitude of heterosis as well as both the general (GCA) and specific (SCA) combining ability efffects.

\section{Materials And Methods}

Six roselle parental cultivars namely Bazza-AB1, Gerio-AB1, Bazza-AB2, Gerio-AB2, Gerio-AB3 and Michika-AB1 were selected for this study on the basis of their divergence of characteristic, such as days to maturity, fruit colour, stem shape, size and prickly hair. All the cultivars were collected from Yola and Michika LGA of Adamawa State.

During the 2009 cropping season, crosses were made in all possible combination between the six cultivars excluding the reciprocals. All the $\mathrm{F}_{1}$ and the six parents were evaluated in a randomize complete block design with three replications during the 2010 cropping season at Yola and Mubi. Each plot consist of 12 plants planted in three rows with four plants each. Spacing was $80 \mathrm{~cm}$ between rows and $60 \mathrm{~cm}$ within rows. Cultural practices were followed, such as weeding and fertilizer application. Data were collected for (1) plant height, (2) number of branches per plant, (3) branch length, (4) days to 50\% flowering, (5) number of flowers per plant, (6) number of calyx per plant, (7) fruit length, (8) fruit weight,(9) number of seeds per pod (10) calyx yield per plant.

\section{Results}

The mean squares from the analysis of variance combined across the two locations for all the traits are presented in Table 1. The mean squares due to location were highly significant $(\mathrm{P} \leq 0.01)$ for days to $50 \%$ flowering, number of calyx per plant and number of seeds per pod and significant $(\mathrm{P} \leq 0.05)$ only for fruit weight per plant, while number of flowers per plant, number of branches, branch length, plant height, fruit length and calyx yield per plant were not significant. The mean squares due to entries, parents and crosses showed highly significant differences for all the traits except calyx yield per plant, indicating that the genotypes under study were highly variable for all traits. Similarly, the variance for both GCA and SCA were also highly significant for all traits indicating that the additive and non-additive genetic makeup of the genotypes were also highly variable.

Table 1: Mean square estimates of traits in a 6 x 6 half diallel cross of local roselle cultivars across location

\begin{tabular}{|c|c|c|c|c|c|c|c|c|c|c|c|}
\hline $\begin{array}{l}\text { Source of } \\
\text { variation }\end{array}$ & $\begin{array}{l}\text { D } \\
\text { F }\end{array}$ & $\begin{array}{l}\text { Days to } \\
50 \% \\
\text { floweri } \\
\text { ng }\end{array}$ & $\begin{array}{l}\text { No. of } \\
\text { calyx } \\
\text { per } \\
\text { plant }\end{array}$ & $\begin{array}{l}\text { No. } \\
\text { of } \\
\text { flowe } \\
\text { r per } \\
\text { plant }\end{array}$ & $\begin{array}{l}\text { No. of } \\
\text { branch } \\
\text { es per } \\
\text { plant }\end{array}$ & $\begin{array}{l}\text { Branch } \\
\text { length } \\
(\mathrm{cm})\end{array}$ & $\begin{array}{l}\text { Plant } \\
\text { height } \\
(\mathrm{cm})\end{array}$ & $\begin{array}{l}\text { Fruit } \\
\text { lengt } \\
\mathrm{h} \\
(\mathrm{cm})\end{array}$ & $\begin{array}{l}\text { Fruit } \\
\text { weight }(\mathrm{g}) \\
\text { per plot }\end{array}$ & $\begin{array}{l}\text { No. } \\
\text { of } \\
\text { seeds } \\
\text { per } \\
\text { pod }\end{array}$ & $\begin{array}{l}\text { Calyx } \\
\text { yield } \\
\text { per } \\
\text { plant }(g)\end{array}$ \\
\hline Location & 1 & $848.68^{*}$ & $127.80^{*}$ & $0.84^{\mathrm{ns}}$ & $3.80^{\mathrm{ns}}$ & $88.78^{\text {ns }}$ & $1.14^{\mathrm{ns}}$ & $0.01^{\mathrm{ns}}$ & $17271.08^{*}$ & $7.14^{* * *}$ & $1.92^{\mathrm{ns}}$ \\
\hline $\begin{array}{l}\text { Rep/Locati } \\
\text { on }\end{array}$ & 4 & $3.76^{\mathrm{ns}}$ & $57.49^{* *}$ & $2.12^{\mathrm{ns}}$ & $1.54^{\mathrm{ns}}$ & $88.74 *$ & $104.56^{*}$ & $0.08^{\mathrm{ns}}$ & $45576.04^{*}$ & $0.33^{* *}$ & $47.66^{\mathrm{ns}}$ \\
\hline Entries & 20 & $78.50^{* * *}$ & $897.40^{*}$ & ${ }_{* *}^{43} .81$ & $34.63^{* *}$ & 1380.40 & $\begin{array}{l}3076.52 \\
* *\end{array}$ & $3.22^{*}$ & $\begin{array}{l}410994.7 \\
4^{* * *}\end{array}$ & 26.57 & $\underset{* *}{4286.89}$ \\
\hline Parents & 5 & $89.33^{\text {*** }}$ & 1116.38 & 51.31 & $65.15^{* *}$ & 2410.62 & 2235.82 & $3.93^{*}$ & 608120.4 & 29.01 & $\begin{array}{l}67.69 .4 \\
8^{*}\end{array}$ \\
\hline Crosses & 14 & $97.30^{* * *}$ & 1114.33 & 51.46 & $46.93^{* *}$ & 1687.90 & $\underset{* *}{3826.35}$ & ${ }_{*}^{1.83^{*}}$ & $\begin{array}{l}451089.6 \\
1^{* * *}\end{array}$ & 28.30 & 4780.19 \\
\hline GCA & 5 & $234.4^{* * *}$ & ${ }_{*} 163.81^{*}$ & $4.56^{* *}$ & $10.99^{* *}$ & $391.38^{*}$ & $324.47^{*}$ & $1.51^{*}$ & ${ }_{*} 163166.6^{*}$ & 13.32 & $1734.7^{*}$ \\
\hline SCA & 15 & $3_{*}^{310.58^{*}}$ & $149.24^{*}$ & $8.42^{* *}$ & $7.29^{* *}$ & $200.60^{*}$ & $512.70^{*}$ & $0.91^{*}$ & $46278.9^{* * *}$ & 14.27 & ${ }_{*}^{920.65^{*}}$ \\
\hline $\begin{array}{l}\text { Ratio } \\
\delta^{2} \mathrm{GCA} / \delta^{2} \\
\text { SCA }\end{array}$ & & 0.009 & 0.13 & 0.04 & 0.21 & 0.29 & 0.07 & 0.21 & 0.47 & 0.11 & 0.24 \\
\hline $\begin{array}{l}\text { Pooled } \\
\text { error }\end{array}$ & & 1.72 & 12.80 & 1.12 & 0.97 & 31.69 & 17.31 & 0.03 & 2494.17 & 0.32 & 20.54 \\
\hline
\end{tabular}

$*$ significant at $(\mathrm{P}=0.05), * *$ significant at $(\mathrm{P}=0.01), \mathrm{ns}=$ not significant

The estimates of general combining ability (GCA) effects pooled over the two locations for all the traits studied are presented in Table 2. The results revealed that Gerio-AB3 and Bazza-AB1 followed by Bazza-AB2 were the highest general combiners for most of the traits studied. This is because they showed a relatively high positive GCA effects for most of the traits measured. Comparatively, Gerio-AB3 is considered the overall best general combiner because it showed positive GCA effects for seven traits viz: number of calyx per plant, number of 
flowers per plant, number of branches per plant, branch length, fruit weight per plot, number of seeds per pod and calyx yield per plant. Bazza-AB2 and Bazza-AB1 were considered to be the second and third best general combiners respectively.

Bazza AB2 showed positive GCA for six traits which include the number of calyx per plant, number of flowers per plant, number of branches per plant, branch length, plant height and fruit length. Gerio AB1 showed positive GCA for only four traits, while Michika AB1 showed negative GCA for all the traits studied except plant height and fruit length.

Table 2: General combining ability effects of roselle cultivars in yield per plant and its components, combined

\begin{tabular}{|c|c|c|c|c|c|c|c|c|c|c|}
\hline Genotype & $\begin{array}{l}\text { Days to } \\
50 \% \\
\text { flowerin } \\
\mathrm{g}\end{array}$ & $\begin{array}{l}\text { No. of } \\
\text { calyx } \\
\text { per } \\
\text { plant }\end{array}$ & $\begin{array}{l}\text { No. of } \\
\text { flower } \\
\text { per } \\
\text { plant }\end{array}$ & $\begin{array}{l}\text { No. of } \\
\text { branch } \\
\text { per } \\
\text { plant }\end{array}$ & $\begin{array}{l}\text { Branc } \\
\mathrm{h} \\
\text { lengt } \\
\mathrm{h} \\
(\mathrm{cm})\end{array}$ & $\begin{array}{l}\text { Plant } \\
\text { heig } \\
\text { ht } \\
(\mathrm{cm})\end{array}$ & $\begin{array}{l}\text { Fruit } \\
\text { lengt } \\
\mathrm{h} \\
(\mathrm{cm})\end{array}$ & $\begin{array}{l}\text { Fruit } \\
\text { weight } \\
\text { (g) per } \\
\text { plot }\end{array}$ & $\begin{array}{l}\text { No. of } \\
\text { seeds } \\
\text { per pod }\end{array}$ & $\begin{array}{l}\text { Calyx yield } \\
\text { per plant }(g)\end{array}$ \\
\hline Bazza AB1 & -8.40 & 4.89 & 0.83 & 1.76 & -2.41 & -4.77 & -0.16 & 223.7 & -1.35 & 23.89 \\
\hline Gerio $\mathrm{AB} 1$ & 5.64 & -1.21 & -0.93 & -1.44 & -8.80 & -1.78 & 0.54 & 2.61 & 1.31 & -10.38 \\
\hline Bazza AB2 & 1.41 & 0.94 & 0.58 & 0.65 & 8.86 & $\begin{array}{l}11.3 \\
4\end{array}$ & 0.54 & -113.08 & -0.49 & -0.19 \\
\hline Gerio AB2 & 4.09 & -4.94 & -0.09 & -0.39 & 1.27 & -3.16 & -0.42 & -174.81 & 0.64 & -16.69 \\
\hline Gerio AB3 & 1.91 & 5.25 & 0.47 & 0.40 & 6.88 & -5.12 & -0.10 & 89.75 & 0.79 & 9.48 \\
\hline $\begin{array}{l}\text { Michika } \\
\text { AB1 }\end{array}$ & -4.65 & -4.92 & -0.85 & -0.98 & -0.81 & 3.49 & 0.39 & -27.64 & -1.88 & -6.10 \\
\hline $\mathrm{SE}(\mathrm{g})$ & 0.59 & 1.63 & 0.48 & 0.44 & 2.56 & 1.89 & 0.08 & 22.79 & 0.25 & 2.08 \\
\hline
\end{tabular}

The specific combining ability (SCA) effects of the crosses for yield and yield components for the 15 crosses are presented in Table 3, out of the 15 crosses, 5 exhibited relatively high positive SCA effects for calyx yield per plant. Bazza-AB2 x Gerio-AB2 exhibited the highest positive SCA followed closely by Bazza-AB1 x Gerio-AB3, which exhibited the second highest positive SCA followed by Gerio-AB1 x Michika-AB1, Bazza-AB2 x Gerio-AB3 and Gerio$\mathrm{AB} 1 \mathrm{x}$ Gerio- $\mathrm{AB} 3$. It is also important to note that for the calyx yield per plant, the two crosses each with the highest positive SCA and negative SCA were also the crosses with the highest and lowest values in the mean performance of the crosses respectively.

The highest estimates of specific combining ability effect for number of calyx per plant were observed in Bazza$A B 2$ x Gerio-AB2, Bazza-AB1 x Gerio-AB3, Bazza-AB1 x Bazza - AB2 and Gerio-AB1 x Michika - AB1. Similarly, high positive SCA effects were observed in the following crosses Bazza-AB2 x Gerio-AB2, Gerio-AB1 x Michika-AB1 and Gerio - AB2 x Gerio-AB3 for plant height. All the crosses which exhibited high SCA effects for this traits also had at least one high general combiner as parents in the cross. For fruit length 8 out of the 15 crosses showed positive SCA effects although their values are low and insignificant.

Slightly more than half and two-thirds of the crosses showed positive SCA for fruit weight per plot and number of seeds per pod respectively. While the remaining crosses had a negative SCA effects for these traits. In this study only $40 \%$ of the crosses showed negative SCA effects, while the remaining $60 \%$ of the crosses had positive SCA effects.

Table 3: Specific Combining ability estimates of 6 roselle cultivars crosses in yield and yield components

\begin{tabular}{|c|c|c|c|c|c|c|c|c|c|c|}
\hline Crosses & $\begin{array}{l}\text { Days to } \\
50 \% \\
\text { floweri } \\
\text { ng }\end{array}$ & $\begin{array}{l}\text { No. of } \\
\text { calyx } \\
\text { per } \\
\text { plant }\end{array}$ & $\begin{array}{l}\text { No. } \\
\text { of } \\
\text { flowe } \\
\text { r per } \\
\text { plant }\end{array}$ & $\begin{array}{l}\text { No. } \\
\text { of } \\
\text { bran } \\
\text { ch } \\
\text { per } \\
\text { plan } \\
\text { t }\end{array}$ & $\begin{array}{l}\text { Branc } \\
\mathrm{h} \\
\text { length } \\
(\mathrm{cm})\end{array}$ & $\begin{array}{l}\text { Plant } \\
\text { height } \\
(\mathrm{cm})\end{array}$ & $\begin{array}{l}\text { Fruit } \\
\text { lengt } \\
\mathrm{h} \\
(\mathrm{cm})\end{array}$ & $\begin{array}{l}\text { Fruit } \\
\text { weight } \\
\text { (g) per } \\
\text { plot }\end{array}$ & $\begin{array}{l}\text { No. of } \\
\text { seeds } \\
\text { per } \\
\text { pod }\end{array}$ & $\begin{array}{l}\text { Calyx yield } \\
\text { per plant }(g)\end{array}$ \\
\hline $\begin{array}{l}\text { Bazza AB1 x } \\
\text { Gerio AB1 }\end{array}$ & 10.23 & -5.81 & -2.74 & $\overline{-}-7.75$ & -6.99 & -5.27 & 0.73 & -244.52 & 3.46 & -25.34 \\
\hline $\begin{array}{l}\text { Bazza AB1 x } \\
\text { Bazza AB2 }\end{array}$ & -17.23 & 5.26 & 1.69 & $-\overline{0.90}$ & -12.39 & -9.04 & 0.25 & 109.08 & -0.10 & -5.71 \\
\hline $\begin{array}{l}\text { Bazza AB1 x } \\
\text { Gerio AB2 }\end{array}$ & 15.44 & -8.15 & 1.69 & - & -16.43 & -3.60 & -0.47 & -100.56 & -8.33 & -19.83 \\
\hline $\begin{array}{l}\text { Bazza AB1 x } \\
\text { Gerio AB3 }\end{array}$ & 5.96 & 22.43 & 6.40 & 5.34 & 18.54 & -29.57 & 0.50 & 442.23 & 1.26 & 41.61 \\
\hline $\begin{array}{l}\text { BazzaAB1 x } \\
\text { Michika AB1 }\end{array}$ & -54.31 & -8.04 & 0.79 & $-\overline{1.90}$ & -6.27 & -3.58 & 0.21 & 3.05 & 1.26 & -1.62 \\
\hline
\end{tabular}




\begin{tabular}{|c|c|c|c|c|c|c|c|c|c|c|}
\hline Gerio AB1 x & 4.45 & -9.06 & -0.93 & - & -11.94 & -8.83 & -0.03 & 179.87 & 1.71 & -26.40 \\
\hline Bazza AB2 & & & & 0.32 & & & & & & \\
\hline $\begin{array}{l}\text { Gerio AB1 x } \\
\text { Gerio AB2 }\end{array}$ & 0.56 & -5.13 & 0.38 & $-\overline{0.54}$ & 0.36 & -46.92 & 0.85 & -92.33 & 0.91 & -30.32 \\
\hline $\begin{array}{l}\text { Gerio AB1 x } \\
\text { Gerio AB3 }\end{array}$ & -6.75 & 0.69 & 2.06 & 1.29 & 1.65 & -17.35 & -0.10 & 37.84 & -1.48 & 7.27 \\
\hline $\begin{array}{l}\text { Gerio AB1 x } \\
\text { MichikaAB1 }\end{array}$ & 3.15 & 2.12 & 1.77 & 2.14 & 13.99 & 27.50 & -0.27 & 109.76 & -1.11 & 24.47 \\
\hline $\begin{array}{l}\text { Bazza AB2 x } \\
\text { Gerio AB2 }\end{array}$ & -5.71 & 26.15 & 4.62 & 5.37 & 27.16 & 33.58 & 0.10 & 225.97 & 2.41 & 61.32 \\
\hline $\begin{array}{l}\text { Bazza AB2 x } \\
\text { Gerio AB3 }\end{array}$ & -0.85 & -8.24 & 0.49 & $-\overline{2.73}$ & 2.17 & -6.17 & -0.80 & -219.45 & 0.72 & 10.84 \\
\hline $\begin{array}{l}\text { Bazza AB2 x } \\
\text { MichikaAB1 }\end{array}$ & 11.38 & -6.59 & -1.37 & $-\overline{1.38}$ & 22.79 & 2.57 & -0.27 & 99.40 & -8.61 & -31.72 \\
\hline $\begin{array}{l}\text { Gerio } A B 2 x \\
\text { Gerio } A B 3\end{array}$ & -5.20 & - & -3.17 & $\begin{array}{l}- \\
3.67\end{array}$ & -3.69 & 5.43 & 1.07 & -142.78 & 6.47 & -47.51 \\
\hline $\begin{array}{l}\text { Gerio AB2 x } \\
\text { MichikaAB1 }\end{array}$ & 9.03 & -2.68 & -0.41 & $\begin{array}{l}- \\
1.56\end{array}$ & -6.56 & -9.43 & 1.84 & -307.62 & 5.14 & -0.11 \\
\hline $\begin{array}{l}\text { Gerio AB3 x } \\
\text { MichikaAB1 }\end{array}$ & 7.21 & $\begin{array}{l}- \\
10.72\end{array}$ & -0.98 & $\begin{array}{l}- \\
1.02\end{array}$ & -5.27 & 2.99 & -0.73 & -165.20 & 0.90 & -19.34 \\
\hline $\mathrm{SE} \pm$ & 1.35 & 3.70 & 1.09 & 1.01 & 5.82 & 4.30 & 0.19 & 51.69 & 0.58 & 4.69 \\
\hline
\end{tabular}

The heterosis over the higher parent cultivar is presented in Table 4. It was observed that heterosis for calyx yield per plant was greatest in crosses where the high yielding parents such as Gerio $-\mathrm{AB} 3$, Bazza-AB1 and Bazza -AB2 were involved in the crosses. Thus, the hybrid, Bazza-AB2 x Gerio-AB2 had the highest heterosis effect of $46.01 \%$ over the higher parent, followed by Bazza-AB1 x Gerio - AB3 and Gerio-AB1 x Michika-AB1. Plate 1 shows examples of parents and hybrids from crosses, where heteroses for the characteristic of the calyx were evident.

Four crosses expressed positive heterosis for number of calyx per plant, namely Bazza-AB2 x GerioAB2, Bazza-AB1 x Gerio-AB3 and Bazza-AB1 x Michika-AB1, all these crosses also expressed positive SCA effects for number of branches per plant thus indicating a close relationship between heterosis and SCA effects. Heterosis was also expressed for fruit length where Gerio-AB3 x Michika-AB1 expressed the highest value followed by Bazza-AB1 x Gerio-AB3, Gerio-AB1 x Gerio AB3, Bazza-AB1 x Gerio -AB1 and Gerio-AB2 x Michika-AB1 in decreasing order of magnitude. Four crosses also exhibited positive heterosis over the higher parent for fruit weight per plot. These were Bazza-AB2 x Gerio-AB2 (54.64), Gerio-AB1 x Bazza-AB2 (8.92), Bazza-AB1 x Gerio-AB3 (12.96) and Gerio-AB1 x Michika-AB1 (0.83). Six crosses expressed negative heterosis for days to $50 \%$ flowering; The lowest being obtained from Bazza-AB2 x Gerio-AB2.

Table 4: Estimates of heterosis (\%) over higher parent of roselle cultivar crosses in yield and yield components,

\begin{tabular}{lllllllllll}
\multicolumn{10}{c}{ combined } \\
\hline Crosses & Days to & No. & No. of & No. of & Branch & Plant & Fruit & Fruit & No. & Calyx \\
& $50 \%$ & of & flower & branches & length & height & length & weight & of & yield \\
& flowering & calyx & per & per plant & $(\mathrm{cm})$ & $(\mathrm{cm})$ & $(\mathrm{cm})$ & $\begin{array}{l}\text { (g) per } \\
\text { seeds }\end{array}$ & per \\
& & per & plant & & & & & plot & per & plant $(\mathrm{g})$ \\
& & & & & & & & pod &
\end{tabular}

\begin{tabular}{lllllllllll}
\hline Bazza AB1 x & 0.61 & - & -12.17 & -25.20 & -42.93 & -19.98 & 7.79 & -36.92 & 9.55 & -39.54 \\
Gerio AB1 & & 26.06 & & & & & & & & \\
Bazza AB1 x & 2.09 & 11.93 & 61.31 & 3.32 & -18.65 & -11.21 & -11.20 & -19.61 & - & -21.43 \\
Bazza AB2 & & & & & & & & & 13.41 & \\
Bazza AB1 x & 7.39 & - & 62.95 & -17.45 & -35.22 & -16.33 & 0.38 & -39.04 & -3.67 & -40.03 \\
Gerio AB2 & & 43.47 & & & & & & & & \\
Bazza AB1 x & -5.28 & 45.41 & 133.58 & 45.08 & 23.05 & 0.91 & 13.59 & 12.96 & 0.88 & 13.21 \\
Gerio AB3 & & & & & & & & & & \\
BazzaAB1 x & 1.07 & 43.10 & 37.78 & -22.05 & -31.02 & -12.30 & 7.98 & -19.92 & -1.99 & -22.54 \\
$\begin{array}{l}\text { Michika AB1 } \\
\text { Gerio AB1 x }\end{array}$ & 4.18 & - & -0.29 & -22.29 & -31.30 & -12.07 & 1.10 & 8.92 & 2.01 & -3.66 \\
$\begin{array}{l}\text { Bazza AB2 } \\
\text { Gerio AB1 x }\end{array}$ & 4.37 & - & 14.60 & 28.17 & -18.01 & -42.03 & 3.47 & -22.09 & 5.93 & -30.11 \\
Gerio AB2 & & 51.30 & & & & & & & &
\end{tabular}


Heterosis And Combining Ability Estimates In 6x6 Half-Diallele Cross Of Roselle (Hibiscus

\begin{tabular}{|c|c|c|c|c|c|c|c|c|c|c|}
\hline $\begin{array}{l}\text { Gerio } A B 1 x \\
\text { Gerio } A B 3\end{array}$ & -4.07 & 22.33 & 42.54 & -9.16 & -15.61 & -43.40 & 12.67 & -5.58 & -0.83 & -12.44 \\
\hline $\begin{array}{l}\text { Gerio AB1 x } \\
\text { MichikaAB1 }\end{array}$ & -1.20 & - & 30.65 & -2.12 & 15.91 & 4.16 & -16.57 & 0.83 & -9.51 & 3.09 \\
\hline $\begin{array}{l}\text { Bazza AB2 x } \\
\text { Gerio AB2 }\end{array}$ & -6.26 & 91.99 & 90.51 & 45.45 & 21.34 & 14.78 & 3.84 & 54.64 & -1.28 & 46.01 \\
\hline $\begin{array}{l}\text { Bazza AB2 x } \\
\text { Gerio AB3 }\end{array}$ & -4.32 & $\begin{array}{l}- \\
33.71\end{array}$ & 38.39 & -28.14 & 15.68 & -9.73 & -8.78 & -0.50 & -3.18 & -2.41 \\
\hline $\begin{array}{l}\text { Bazza AB2 x } \\
\text { MichikaAB1 }\end{array}$ & 1.20 & - & -2.63 & -27.66 & 25.78 & -3.42 & -11.88 & -9.87 & - & -4.86 \\
\hline $\begin{array}{l}\text { Gerio } A B 2 x \\
\text { Gerio } A B 3\end{array}$ & 0.45 & $\begin{array}{l}- \\
67.88\end{array}$ & -23.13 & -47.42 & -3.76 & -9.01 & -5.59 & -0.33 & 9.12 & -32.19 \\
\hline $\begin{array}{l}\text { Gerio AB2 x } \\
\text { MichikaAB1 }\end{array}$ & 5.58 & $\begin{array}{l}- \\
50.19\end{array}$ & 3.92 & -34.08 & -20.60 & -8.44 & 9.24 & -23.18 & 12.98 & -21.94 \\
\hline $\begin{array}{l}\text { Gerio AB3 x } \\
\text { MichikaAB1 }\end{array}$ & -0.75 & $\begin{array}{l}- \\
58.35 \\
\end{array}$ & 1.49 & -27.26 & -6.29 & -6.67 & 23.85 & -23.44 & -1.34 & -28.76 \\
\hline
\end{tabular}

\section{Discussion}

The results obtained in the combined analysis of variance across locations for all traits indicated that entries, parents and crosses showed highly significant differences for all the traits which indicate that there is a sufficient variability exist in these genotypes, which make them amenable to selection pressure.

Model I was used in the estimation of variance components in this study, which were subsequently used to estimate the $\delta^{2} \mathrm{GCA} / \delta^{2} \mathrm{SCA}$ ratio (See Table 1). It was apparent that the non-additive gene effect was found to be more important than the additive gene effect as all the ratios were less than unity. Similar results were reported for yield and yield components in roselle by Gasim (1994). The reason for such findings was probably due to the fact that the parental material used for this study were specifically selected for divergence for most of the traits. This investigation has revealed that both additive and non-additive gene effects were important in the genetic control of all the traits studied. In such a situation, a breeding procedure that would take into consideration the two gene effects simultaneously would be most desirable. In view of this as suggested by Ahmad (2002) a breeding approach which could mop up the fixable additive gene action and at the same time maintain considerable heterozygosity for exploiting the dominance gene action might prove more beneficial in improving this vegetable crop. Combining ability analysis of parent is a vital technique for identifying superior parental material based on their hybrid performance. This helps in selecting best parents which when crossed would give rise to more desirable segregates. A high positive GCA value means the parent line has high potential for generating superior offsprings (Cruz and Regazzi, 1994). Significant GCA effects were found among the parents for the different characteristics estimated. The results indicate that the parent Gerio-AB3 was the best general combiner for most of the characteristics estimated except for plant height and fruit length. Bazza-AB1 had high positive GCA value for calyx yield per plant and hence could be used to improve calyx yield in breeding programmes

Specific combining ability effects are usually used to identify the best cross combinations for hybrid production. It was observed that the best cross combination in terms of SCA effects always involves one or both high general combiners as parents. Most of the crosses involved in this research with high SCA effects involve at least one of the four high general combiners namely Gerio-AB3, Bazza-AB2, Bazza-AB1 and Gerio-AB1. However, the poor general combiners such as Gerio-AB2 and Michika-AB1 could sometimes produce good cross combinations when crossed with high general combiners. Kalia and Padda (1962) suggested that when parents with high GCA cross another with low GCA effects, the poor parents could throw-up desirable transgressive segregates and gives rise to desirable populations. This is only possible if the additive genetic system present in the good general combiners and the complementary epistasis effect present in the cross, act in a complementary fashion to maximize desirable plant attributes which could be exploited in further breeding initiatives.

The results from this study showed that the hybrid Bazza-AB2 x Gerio-AB2 had the largest positive heterosis of $46.01 \%$ over the higher parent and higher SCA effect for calyx yield per plant. Similarly, Bazza$\mathrm{AB} 1 \times$ Gerio-AB3 and Gerio-AB1 x Michika-AB1 were also hybrids with high SCA effect and heterosis value. Aruna et al. (1989) also observed a close relationship between the best specific combiners and hybrids exhibiting high heterotic responses over the higher parents for some of the traits they studied in roselle cultivars. However, Ahmad (2002) cautioned that high heterotic response does not always translate into high performance of hybrids, but it may be due to the relatively poor performance of parents. On the other hand, with the same amount of heterotic response, the SCA effects may be lower when the parental performance is relatively high. 
This therefore suggests that estimates of SCA effects may not always lead to the correct choice of hybrid performance based on heterosis.

This study has indentified a good number of desirable cross combinations for each of the traits studied in the roselle population. The inter-crossing of these materials could therefore generate a population with a large gene pool, where genetic linkages and genetic blocks could be broken. Significant positive heterosis identified in some of the crosses for number of calyx per plant, number of flowers per plant, number of branches per plant and calyx yield per plant indicated over dominance; a likely situation where breeding for hybrid variety is rewarding. The negative values encountered for heterosis, SCA effects and heterosis for some of the traits such as plant height and days to $50 \%$ flowering can also be exploited in the production of tall and early maturing hybrids, respectively.

\section{References}

[1] Adenipekun, I.T. (1998). Extraction and colours of roselle (Hibiscus sabdariffa) juice. M.Sc. Thesis. University of Ibadan, Ibadan (Unpublished).

[2] Ahmad, S. (2002). Inheritance of some characters in Okra (Abelmoschus esculentus L. Moench) under drought conditions. Published $\mathrm{PhD}$ Thesis, Department of Plant Breeding and Genetics, Sindh Agriculture University Tanitojan, Pakistan.

[3] Alegbgejo, M.D. (2000). The potential of Roselle as an industrial crop in Nigeria. NOMA Magazine 14:1-3.

[4] Aruna,C., Subramanyam,D., Kumar, P.V.R and G. Salyanarayana (1989). Correlation and path roselle (Hibiscus sabdariffa L.). Journal of Research APAU 17:65-67.

[5] Cruz, M. and I. Regazzi (1994). General Combining Ability estimates of some agronomic characters on roselle (Hibiscus sabdariffa L.) M.Sc Thesis, Faculty of Agriculture, University of Khartoum, Sudan.

[6] Flint-Garcia S.A, Buckler E.S, Tiffin P, Ersoz E, Sringer N.M (2009). Heterosis is prevelant for multiple traits in diverse maize germplasm. 4: e7433.

[7] Gasim, S.M. (1994). Genetic variability of some agronomic characters on roselle (Hibiscus sabdariffa L.) M.Sc Thesis, Faculty of Agriculture, University of Khartoum, Sudan.

[8] Ghazali, M. (1999). Characterization and utilization of roselle. Food Science and Biotechnology on-line. University of Putra, Malaysia.

[9] Howard, A. and G.L.C Howard (1911). Studies in India fibre plant, no. 2 on some row varieties of Hibiscus cannabinus L. and Hibiscus sabdariffa L. Indian Department of Agriculture. Agric. Mem. Bott. Serv. 4: 9-36.

[10] Ibrahim. M.M. and R.M. Hussien (2006). Variability, Heritability and genetic advance in some genotypes of roselle. Cytology Department, National Research Centre (NRC), Dokki, Cairo, Egypt.

[11] Kalia, H.R. and D.S. Parda (1962). Inheritance of some fruit characters in okra. Indian Journal of Genetics and Crop Breeding 22(3):248-251

[12] Sharief, A.E, El-Kalla S.E, Gado H.E, Abo-Yusuf H.A (2009) Heterosis in yellow maize. Austrialian Journal Crop Science 3: 146156

[13] Vaidya, K.R. (2000). Natural Cross-pollination in roselle (Hibiscus sabdariffa L.) 23(3): 667-669. 